\title{
Post Lumber Punction Headache in Pediatric Cases
}

\section{Pediatrik Olgularla Lomber Ponksiyon Sonrası Baş Ağrısı}

\author{
Özlem Yayıcı Köken ${ }^{1^{*}}$, Ayşegül Danış $^{2}$, Ülkühan Öztoprak ${ }^{3}$, Ayşe Aksoy $^{4}$, Deniz Yüksel $^{3}$ \\ 1 Ankara City Hospital, Childrens' Hospital, Department of Pediatric Neurology, Ankara, Turkey \\ ${ }^{2}$ Bolu İzet Baysal Education and Research Hospital, Department of Pediatric Neurology, Bolu, Turkey \\ ${ }_{3}^{3}$ SBÜ, Dr Sami Ulus Research and Training Hospital, Department of Pediatric Neurology, Ankara, Turkey \\ 4 Samsun Ondokuz, Mayıs University, Faculty of Medicine, Department of Pediatric Neurology, Samsun, Turkey
}

\begin{abstract}
Objective: Lumbar puncture (LP) is a frequently used as a diagnostical and treatment tool in the practice of pediatric neurology. Headache associated with LP directly effects the physician and the family concerning patient comfort in a negative manner. The aim of this study is to evaluate and present to the literature, the clinical features, treatment strategies and prognoses of 8 cases with postdural puncture headache (PDPH).

Materials and Methods: Eight cases with clinical findings who underwent LP for various reasons and diagnosed as PDPH in the last three years at the pediatric neurology department of SBU, Ankara Dr. Sami Ulus Training and Research Hospital were retrospectively evaluated.

Results: The patients' mean age were 12.2 and $4(50 \%)$ of them were male. Headache started within first 4 hours in 5 patients while 3 patients reported pain within the first hour after LP. Headaches, which were accompanied by a sensation of pressure and/or throbbing were located occipitally in $2(25 \%)$, frontally in $2(25 \%)$, frontotemporally in $1(12,5 \%)$, bitemporally in 1 $(12,5 \%)$ patient while it extended to the neck in $2(25 \%)$ patients. All patients were supported with increased liquid intake, absolute bed rest, feet elevation, intravenous hydration and paracetamol while 6 patients were given oral caffeine. The pain gradually disappeared in an average of 2,7 days while it took relatively longer in 2 patients who were overweight and obese.

Conclusion: Although PDPH is a frightening situation by both the clinician, the patient and the parents; it can usually be controlled with supportive treatment and has a benign course.

Key Words: Lomber punction, headache, postdural punction headache
\end{abstract}

\section{Objective}

Lumbar punction (LP) is an invasive procedure performed to evaluate the histology and biochemistry of the cerebrospinal fluid (CSF), to measure the CSF pressure and to apply intrathecal treatments which is widely carried out in the pediatric neurology practice. The postural puncture headache (PDPH), also known as post LP headache, is thought to be caused by a

\begin{abstract}
Özet
Amaç: Lomber ponksiyon (LP), çocuk nörolojisi pratiğinde tanısal ve son yıllarda tedavi amaçlı sık kullanılan girişimdir. LP sonrası ve LP ilişkili gelişen; 'Lomber ponksiyon baş ağrısı' ise nadir görülen bir durum olup; hekim ve aile açısından hasta konforunu da doğrudan etkileyen bir semptomatolojiye neden olur. Bu çalışmada; postdural ponksiyon baş ağrısı (PDPBA) tanıs1 alarak izlenen 8 olgunun klinik özellikleri, tedavi stratejileri ve prognozları değerlendirilerek literature sunulması amaçlanmıştır.
\end{abstract}

Gereç ve Yöntem: Sağlık Bilimleri Üniversitesi (SBÜ), Ankara Dr. Sami Ulus Kadın Doğum, Çocuk Sağlığı ve Hastalıkları SUAM, çocuk nörolojisi kliniğince değerlendirilerek, son 3 yılda farklı nedenlerle LP uygulanan ve PDPBA tanisı alan 8 olgunun klinik bulguları retrospektif olarak değerlendirilmiştir.

Bulgular: Ortalama yaşları 12.2, \% 50'si erkek $(\mathrm{n}=4)$ hastaların tamamında ilk 4 saatte baş ağrısı ortaya çıkarken, 4 hastada (\% 50) ilk 1 saatte baş ağrısı başlamıştır. Zonklayıcı ve/veya sıkıștırıcı tarzda olan baș ağrıları; 2 hastada (\% 25) ensede, 3 hastada $(\%$ 37,5) şakaklarda, $1(\%$ 12.5)'inde ise her iki temporal bölgedeyken, 2 (\% 25) hastada boyuna yayıldığı tariflenmişti. Tüm hastalara bol sivi tüketimi, mutlak yatak istirahati, ayak elevasyonu, intravenöz hidrasyon, oral parasetamol ve 6 hastaya oral kafein desteği verildi. Ağr1 ortalama 2,7 günde azalarak kesildi ancak fazla kilolu ve obez olan 2 hastada ağrının görece daha uzun sürdüğü kaydedildi.

Sonuç: Postdural ponksiyon baş ağrısı; hem uygulayıcı klinisyen hem de hasta ve ebeveynler tarafindan korkutucu bir durum olmasina ragmen; genellikle destek tedavi ile kontrol altına alınabilir ve selim seyir gösterir.

Anahtar Kelimeler: Lomber ponksiyon, baş ağrısı, postdural ponksiyon baṣ ağrısı

drop in the CSF pressure as a result of leakage from the dura and arachnoid damaged during the punction. Its incidence in the adult population has been reported between $10-70 \%$ in different studies (1-5). There is not enough data on its incidence in childhood. Third edition of the International Classification of Headache Disorders (ICHD-3) 5

*Sorumlu Yazar: Özlem Yayıc1 Köken, Ankara City Hospital, Childrens’ Hospital, Department of Pediatric Neurology, Üniversiteler Street. Bilkent/Ankara E-mail: drozlemkoken@gmail.com Tel: 905307624200 Orcid: Özlem Yayı1 Köken 0000-0003-2112-8284, .Ayşegül Danış 0000-0003-0962-2116, Ülkühan Öztoprak, 0000-0002-7309-3215,.Ayşe aksoy 0000-0001-7533-1638, .Deniz Yüksel, 0000-0001-8990-023X

Geliş Tarihi:25.10.2020, Kabul Tarihi:13.01.2021 
defines the postlumbar headache as occurring within 5 days after a lumbar puncture, caused by CSF leakage through the dura. It is accompanied by subjective hearing symptoms and/or neck stiffness. It ships spontaneously within 2 weeks, or after covering of the leak with autologous epidural lumbar patch. Diagnostic criteria are defined as follows: (1) Headache fulfilling criteria for 7.2 headache attributed to low CSF pressure, and criterion 3 below, (2) Dural puncture has been performed, (3) Headache has developed in 5 days of the dural puncture and (4) Not better accounted for by another ICHD-3 diagnosis (5). To diagnose PDPH by ICHD-3 criterias, clinicians have to know headache fulfilling the criteria for 7.2 which is defined as; (1) any headache fulfilling the criterion 3, (2) either or both of the following: 1. Low CSF pressure $(<60 \mathrm{~mm}), 2$. Evidence of leakage on imaging, (3) headache developed in temporal relation to the low CSF pressure of CSF leakage, or its discovery, (4) not better accounted for another ICHD-3 diagnosis. Also, ICHD-3 criterion stated in 3 points; (1) headache related with low CSF pressure is usually but not invariably orthostatic, (2) brain imaging shows brain sagging or pachymeningeal enhancement, or spine imaging shows extradural CSF, (3) exclusion of other diagnosis together with temporal relation to the possible etiology of low CSF pressure. But also, there is no reported diagnostic criterias and algorithms for childhood PDPH. So that; diagnostic criterias and management of adult population is adopted for the pediatric cases by clinicians. Here, in this study, our aim is to retrospectively evaluate 8 patients with normal CSF microscopic examinations, pressure, biochemistry and neuroimaging who were diagnosed with PDPH according to ICHD-3 criterion in the pediatric neurology department and present them as a case series with clinical findings, treatment strategies and prognosis.

\section{Material and Method}

This retrospective, observational and descriptive study was conducted at University of Health Sciences Ankara Dr Sami Ulus Maternity, Child Health and Diseases Training and Research Hospital, Department of Pediatric Neurology and planned by following the rules of Helsinki Declaration and written informed consent was obtained from all patients' parents or legal guardians of the children included. Demographic (age and gender), clinical data and characteristics of the PDPH (body mass index, headache localization and duration, The Wong-Baker Faces scale results) and treatment strategies were evaluated from hospital records. Pediatric patients who met the criteria for PDPH of the ICHD- $3^{5}$ and whose CSF microscopic examinations, pressure (between $11.5 \mathrm{~cm}-25 \mathrm{~cm}$ of water), biochemistry and neuroimaging were within normal limits were included to the study. Patients with CSF abnormalities were not included to the study if CSF pressure could alter by affecting PDPH characteristics.

Lomber Punction Procedure: The patients were given normotonic fluid infusions adjusted for their diagnosis and weight in addition to intravenous midazolam $0,15 \mathrm{mg} / \mathrm{kg}$ for premedication. Blood pressure, heart rate and peripheral oxygen saturation were monitored. The lumbar puncture was performed by the same pediatric neurology specialist in the L3-L4 intervertebral space using a 22G Quincke spinal needle following the sterilization of the lumbar area in the lateral decubitus position. The CSF pressure was measured following the observation of free flow and 2-4 milliliters of CSF samples were obtained.

Management of Pain: Increased liquid intake, absolute bed rest, feet elevation were recommended to all patients diagnosed as PDPH. Pain was evaluated using The Wong-Baker Faces scale (WBS) was recorded in erect and lying position which is routinely used in our clinic. Patients who reported their pain as greater than 1 were given bed rest, oral and intravenous hydration and patients who reported their pain as 3 or more were given additional oral paracetamol two times a day with the dosage of $10 \mathrm{mg} / \mathrm{kg}$. Oral caffeine was recommended to all patients.

Statistical Analysis: Data were analyzed using SPSS ${ }^{\circledR} 21$ (IBM Inc, USA) software for statistical analysis. Categorical data were evaluated using frequency and percentages while numerical data were evaluated using averages and standard deviation.

\section{Results}

Demographic and clinical data are summarized in the table. The patients' average age was 12.2 years (61-212 months) and 50\% ( $\mathrm{n}=4)$ were males. There were no hematomas in the puncture area. There were no failed lumbar puncture attempts and no further attempts were necessary. Hemodynamic parameters weres table throughout and following the procedure in all patients. All patients were recommended to increase fluid intake and rest in a supine position after the procedure. Microscopic examination, biochemistry and the pressure of the CSF and 
Table: Demographic and clinical features of 8 patients who were diagnosed with PDPH following LP

\begin{tabular}{|c|c|c|c|c|c|c|c|c|c|}
\hline $\begin{array}{l}\text { Patient demographic } \\
\text { and clinical features }\end{array}$ & \multicolumn{2}{|c|}{$\begin{array}{c}\text { Age } \\
\text { (years old) }\end{array}$} & $\begin{array}{ll}\text { Sex } & \text { BMI }\end{array}$ & $\begin{array}{c}\text { Sedation } \\
\text { technique }\end{array}$ & $\begin{array}{c}\text { Headache } \\
\text { onset }\end{array}$ & Headache location & $\begin{array}{c}\text { WBS } \\
\text { Erect/Lying }\end{array}$ & $\begin{array}{c}\text { Pain } \\
\text { duration } \\
\text { (Days) }\end{array}$ & Treatment \\
\hline 1 & 15 & $\bar{M}$ & $19 \mathrm{~kg} / \mathrm{m}^{2}$ & Midazolam & $1 \mathrm{~h}$ & Occipital & $4 / 3$ & 2 & $\begin{array}{c}\text { iv hydration } \\
\text { Oral caffeine } \\
\text { Paracetamol }\end{array}$ \\
\hline 2 & 17 & $\mathrm{~F}$ & $\begin{array}{l}25.6 \mathrm{~kg} / \mathrm{m}^{2} \\
33.4 \mathrm{~kg} / \mathrm{m}^{2}\end{array}$ & Midazolam & First hour & $\begin{array}{l}\text { Cannotbe localized } \\
\text { initiallyand neck }\end{array}$ & $5 / 4$ & 3 & $\begin{array}{l}\text { iv hydration } \\
\text { Feet elevation } \\
\text { Oral caffeine } \\
\text { Paracetamol }\end{array}$ \\
\hline 3 & 18 & $\mathrm{~F}$ & $20.0 \mathrm{~kg} / \mathrm{m}^{2}$ & $\begin{array}{l}\text { Midazolam } \\
\text { Ketamine }\end{array}$ & $3-4 \mathrm{~h}$ & Bitemporal & $5 / 3$ & 4 & $\begin{array}{l}\text { iv hydration } \\
\text { Feet elevation } \\
\text { Oral caffeine } \\
\text { Paracetamol }\end{array}$ \\
\hline 4 & 16 & M & $34.2 \mathrm{~kg} / \mathrm{m}^{2}$ & Midazolam & $1-2 \mathrm{~h}$ & Frontal & N/A & 2 & $\begin{array}{l}\text { iv hydration } \\
\text { Feet elevation } \\
\text { Paracetamol }\end{array}$ \\
\hline 5 & 11.5 & $\mathrm{~F}$ & $21 \mathrm{~kg} / \mathrm{m}^{2}$ & Midazolam & $2-3 \mathrm{~h}$ & Frontaland temporal & N/A & 3.5 & $\begin{array}{c}\text { iv hydration } \\
\text { Feet elevation } \\
\text { Oral caffeine } \\
\text { Paracetamol }\end{array}$ \\
\hline 6 & 5 & M & $23 \mathrm{~kg} / \mathrm{m}^{2}$ & Midazolam & $1 \mathrm{~h}$ & Cannotbe localized & $4 / 2$ & 2 & $\begin{array}{c}\text { iv hydration } \\
\text { Feet elevation } \\
\text { Oral caffeine } \\
\text { Paracetamol }\end{array}$ \\
\hline 7 & 10.5 & M & $25 \mathrm{~kg} / \mathrm{m}^{2}$ & Midazolam & $2 \mathrm{~h}$ & Occipitalandneck & $3-4 / 3$ & 3 & $\begin{array}{l}\text { iv hydration } \\
\text { Feet elevation } \\
\text { Paracetamol }\end{array}$ \\
\hline 8 & 17.5 & $\mathrm{~F}$ & & Midazolam & $2-3 \mathrm{~h}$ & Frontal & $5 / 4$ & 2 & $\begin{array}{c}\text { iv hydration } \\
\text { Feet elevation } \\
\text { Oral caffeine } \\
\text { Paracetamol }\end{array}$ \\
\hline
\end{tabular}


neuroimaging were within normal range in all patients.In all patients, the onset of headache was within the 4 hours of the LP while headache started within the first hour in $4(50 \%)$ patients. Headaches, which were accompanied by a sensation of pressure and/or throbbing were located occipitally in $2(25 \%)$, frontally in $2(25 \%)$, frontotemporally in $1(12,5 \%)$, bitemporally in 1 $(12,5 \%)$ patient while it extended to the neck in 2 $(25 \%)$ patients. The WBS was recorded in erect and lying position for 6 patients. Wong Baker Faces scale was greater than 2 in all patients and thus, 1 of the patients refused feet elevation. Oral caffeine was recommended to all patients, however only six $(75 \%)$ complied. Headache gradually disappeared in 2,7 days (2-4 days) but this period was relatively longer in two patients who were obese.

\section{Discussion}

In this study, it has been shown that PDPH does not show a specific pain location, but increases in erect position, lasts for an average of 2-3 days, and has an excellent prognosis with supportive treatment in pediatric cases. PDPH is one of the most common situations associated with LP. The lower incidence in childhood could be explained by the fact that LP is performed much less in this age group than young women undergoing LP for obstetric reasons and the fact that it could be reported less since it has a benign course in this age group. According to Fishman et al, the incidence of PDPH is as high as $70 \%$ in the adult population ${ }^{6}$. Some studies report a higher incidence in young people and women and propose that this is caused by a more elastic dura with a higher collagen content compared to older people which delays the closure of the dural defect. The exact pathophysiological mechanism of PDPH is still not clear. It is believed to be secondary to the drop in CSF pressure due to leakage from the dura damaged by the needle. Cerebrospinal fluid volume and pressure drops when synthesis cannot compensate for the lost amount. Subarachnoid pressure drops below 4 $\mathrm{mmHg}$ which is normally between 5 and 10 mmHg. A $10 \%$ decrease in CSF pressure causes orthostatic headache (2,7-10). Studies state that PDPH is a result of increased tension on the painsensitive structures in the cranial cavity or cerebral vasodilation secondary to adenosine release triggered by the drop in the CSF pressure (10). The risk may increase in case of a longer duration of CSF leakage and when a large quantity of sample is taken. A major point in our patients who had normal CSF cytology is the possible contribution of inflammatory cells which might have been present or migrated to the CSF in the process of healing the postdural CSF leakage. Presence of leukocytes in the CSF in meningitis and multiple sclerosis has been shown to significantly reduce the PDPH incidence ${ }^{12,13}$. Some authors state that the increased intraabdominal pressure in obese patients help seal the dural defect thus minimizing the CSF leakage which is another evidence supporting the notion that PDPH risk decreases when CSF leakage is prevented ${ }^{14}$. Lower body mass index has been associated with an increased risk of PDPH in adults (14). One of the major points of interest is whether being overweight or obese is associated with PDPH in pediatric patients. The duration of headache was relatively longer in our obese patients in the absence of failed or repetitive LP attempts however, this observation needs to be tested in studies with a bigger sample size. In studies where the relationship between the experience level of the physician, shape, thickness, bevel orientation of the needle and the incidence PDPH is evaluated, the risk has been reported to increase when a sharp/thick needle is used and repetitive attempts are made thus causing more dural defects $(15,16)$. The diameter of the dura defect is directly correlated to the amount of CSF lost, thus increasing the risk of PDPH. On the other hand, the thicker the needle, the greater the risk of failure (8-14). The shape of the needle tip is also associated with dura defects. Westbrook et al and Ready et al, in which studies pencil point needles and sharp needles of the same diameter were compared, found out that pencil point needles caused less CSF loss and stated that this could explain the pathophysiologic mechanism of lesser pain. This type of bevel separates the longitudinal dural fibers instead of cutting them, thus decreasing the trauma to the dura $(10,17,18,19)$. We used $22 \mathrm{G}$ Quincke type spinal needles and did not perform a comparison of needle sizes and shapes. Headache, which is the main symptom of PDPH, typically starts within 15 minutes of erect position and gradually diminishes in 30 minutes when lying down. In our study; a more severe pain in erect position (standing up or sitting in bed) was confirmed by the scale measurements. But, this definition is important in the distinction between PDPH and a migraine without aura. Features such as the location, duration and severity of headaches have not been 
clearly defined and pain properties from adult studies where spinal anesthesia were performed have been adapted. Although the usual onset of headache is within 72 hours of LP, cases with an onset of 1-12 days have also been reported. In our study, the average onset of PDPH was within four hours, and within the first hour after LP in majority of cases. The headache is often localized frontally or occipitally but can extend to the neck and shoulders in rare cases (1-3). In our patient group, the headaches had a throbbing or pressing quality and were localized occipitally and frontally with 3 patients reporting pain extending to the neck. The headache is known to get worse with movement or standing up, as supported by WongBaker faces scale in our study (1-7). Other symptoms such as nausea, vomiting, dizziness, tinnitus, hearing loss and vertigo secondary to low CSF pressure can be found. Rarely, neck stiffness or crainal nerve paralysis can be seen (1-6). None of our cases reported these symptoms. In a study concerning the recovery from PDPH with an adult cohort of 10,098 patients where the patients were observed daily for two weeks and were followed up for 6 months following spinal anesthesia, $72 \%$ of the patients reported being pain free within 7 days while pain had completely disappeared in 6 months in $87 \%$ of the patients $(6,19)$. In our study, pain had receded in all patients within one week although overweight and obese patients (n:2) reported a relatively longer pain duration. Bed rest is often recommended for the prevention of postdural puncture headaches. However, studies found no difference concerning the incidence and severity of pain between bed rest and mobilization $(20,21)$. It has been reported that bed rest after LP does not prevent postdural puncture headache but is effective in reducing the pain once it develops. Conservative methods such as bed rest, feet elevation, corsets for increasing the intraabdominal pressure and pharmacologic methods such as steroids, hydration and/or oral or intravenous caffeine can be utilized for the management of postdural puncture headache. However, there have been conflicting reports about the success of these methods (22). Epidural blood patch has yielded successful results in the treatment of adult patients where the mentioned treatments have failed $(11,23)$. Although this method has given good results in pediatric patients, it has been used in a limited number of patients (23). Another invasive method used in adults is the transnasal sphenopalatine ganglion blockade (24). Our study showed that PDPH has a good prognosis with supportive treatment in pediatric ages. Nevertheless, our results need to be confirmed by further prospective studies conducted with more extensive patient series.

Acknowledgements: All authors thank all the patients and family members for their participation in this study. Conflict of Interest: There is no conflict of interest.

Conflict of Interests: The authors have no conflict of interest.

\section{References}

1. Evans RW, Armon C, Frohman EM, Goodin DS. Assessment: prevention of post-lumbar puncture headaches. Report of the therapeutics and technology assessment subcommittee of the American Academy of Neurology. Neurology 2000; 55(7):909-914.

2. Reid JA, Thorburn J. Headache after spinal anaesthesia. Br J Anaesth 1991;67:674-7.

3. Dripps RD, Vandam LD. Hazards of lumbar puncture. J Am Med Assoc 1951; 147 (12): 1118-1121.

4. Vandam LD, Dripps RD. Long-Term Follow-Up of Patients who Received 10,098 Spinal Anesthetics: Stndrome of Decreased Intracranial Pressure (Headache and Ocular and

Auditory Difficulties). Jama. 1956;161(7):586-591.

5. The International Classification of Headache Disorders, 3rd edition (beta version). Headache Classification Committee of the International Headache Society (IHS). Cephalalgia. Jul 2013; 33(9):629-808.

6. Adler MD, Comi AE, Walker AR. Acute hemorrhagic complication of diagnost ic lumbar puncture. Pediatr Emerg Care Jun. 2001;17(3):184-8.

7. Fishman RA. Cerebrospinal Fluid in Diseases of the Nervous System. WB Saunders, Philadelphia, 1992.

8. Bezov D, Ashina S, Lipton R. Post-dural puncture headache: Part II-prevention, management, and prognosis. Headache. 2010;50(9):1482-98.

9. Wiesel S, Tessler MJ, Easdown LJ. Postdural puncture headache: a randomized prospective comparison of the 24-gauge Sprotte and the 27-gauge Quincke needles in 
young patients. Can J Anaesth. 1993; 40:60711.

10. Hafer J, Rupp D, Wollbruck M, Engel J, Hempelmann G. The effect of needle type and immobilization on postspinal Anaesthesist. 1997; 46:860-6.

11. Vakharia SB, Thomas PS, Rosenbaum AE, Wasenko JJ, Fellows DG. Magnetic resonance imaging of cerebrospinal fluid leak and tamponade effect of blood patch in postdural puncture headache. Anesth Analg. 1997; 84:585-590

12. LeBlanc A, Catrevaux O, Guillaumat C, Robin, L, Foucaud, P. Post lumbar puncture headache in general pediatrics: a prospective multicenter study. Arch. Pediatr. 2005;12 (8), 1199-1203.

13. Stuve O, Cravens, PD, Singh MP., Frohman EM, Phillips JT, Remington G, et al. High incidence of post-lumbar puncture headaches in patients with multiple sclerosis treated with natalizumab: role of intrathecal leukocytes. Arch. Neurol. 2007;64 (7), 10551056.

14. Ghaleb A, Khorasani A, Mangar D. Postdural puncture headache. Int J Gen Med. 2012;5(12):45- 51.

15. Schmittner MD, Terboven T, Dluzak M, Janke A, Limmer ME, Weiss C, et al. High incidence of post-dural puncture he- adache in patients with spinal saddle block induced with $\mathrm{Qu}$ - incke needles for anorectal surgery: a randomised clinical trial. Int J Colorectal Dis. 2010; 25: 775-81

16. Lambert DH, Hurley RJ, Hertwig L, Datta S. Role of needle gauge and tip configuration in the production of lumbar puncture headache. Reg Anesth. 1997; 22:66-72.
17. Westbrook JL, Uncles DR, Sitzman BT, Carrie LE. Comparison of the force required for dural puncture with different spinal needles and subsequent leakage of cerebrospinal fluid. Anesth Analg. 1994; 79:769-72.

18. Ready LB, Cuplin S, Haschke RH, Nessly M. Spinal needle determinants of rate of transdural fluid leak. Anesth Analg.1989;69:457-60.

19. Pirbudak L, Özcan HI, Tümtürk P. Postdural puncture headache: Incidence and predisposing factors in a university hospital. Agri. 2019 Jan;31(1):1-8.

20. Cook PT, Davies MJ, Beavis RE. Bedrest and postlumbar puncture headache: the effectiveness of 24 hours recumbency in reducing the incidence of postlumbar puncture headache. Anaesthesia. 1989; 44:389-391.

21. Hu B, Chen TM, Liu B, Chi W, Miao YQ, Nie XL, et al. Optimal management after paediatric lumbar puncture: a randomized controlled trial. BMC Neurol. 2019 Apr 13;19(1):64

22. Van de Beek, D., Brouwer, M. C. Atraumatic lumbar puncture needles: practice needs to change. The Lancet. 2018; 391; 1128-1129.

23. Klepstad P. Relief of postural post dural puncture headache by an epidural blood patch 12 months after dural puncture. Acta Anaesthesiol Scand. 1999;43:964-6.

24. Jespersen MS, Jæger PT, Ægidius KL, Meyhoff CS. Sphenopalatine ganglion block for treatment of post-dural puncture headache. Ugeskr Laeger. 2019 May. 6; (19):181. 